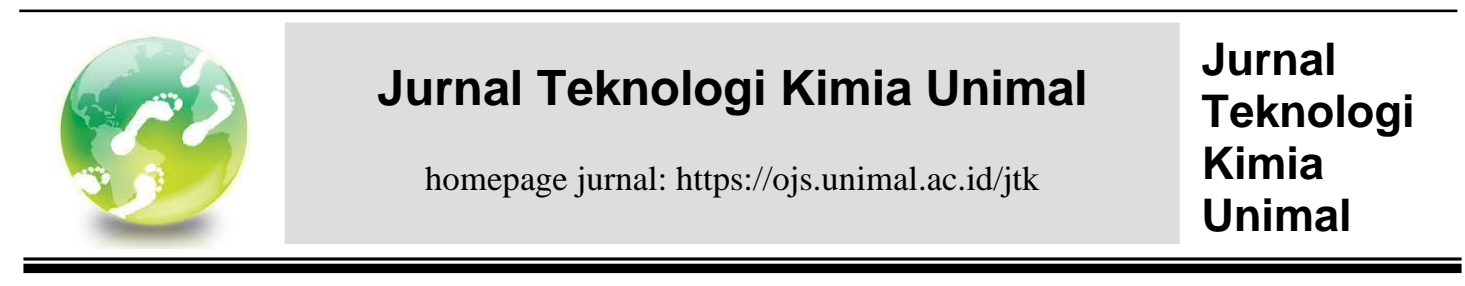

\title{
HIDROLISIS LIGNOSELULOSA DAN KARAKTERISASI LIGNIN DARI MATERIAL LIMBAH KELAPA DENGAN METODE HIDROLISIS ASAM SULFAT
}

\author{
Cindy Yulia Febriani ${ }^{1,2}$, Lindawati ${ }^{1}$ \\ ${ }^{1}$ Jurusan Teknik Kimia, Fakultas Teknik, Universitas Surya \\ ${ }^{2} \mathrm{PT}$. DBFF Boton Indonesia \\ Great Western Resort 1st Floor Unit F8 - F9, Jl. M.H. Thamrin KM 2.7, Tangerang \\ 15143 - Banten \\ Korespondensi: HP: +62-81398301792, e-mail: cindyyuliaf@gmail.com
}

\begin{abstract}
Abstrak
Penelitian ini melakukan hidrolisis lignoselulosa menggunakan asam sulfat dengan limbah kelapa berupa batok dan sabut kelapa untuk memeroleh zat lignin. Rasio padatan:larutan yang digunakan sebesar 3:25 ( $\mathrm{m} / \mathrm{v})$. Variasi waktu pemanasan 2 hingga 5 jam. Lignin tidak larut asam yang diperoleh diuji karakterisasi menggunakan FT-IR dan SEM. Rata-rata yield lignin tidak larut dan larut asam pada batok kelapa lebih besar daripada sabut kelapa. Gugus metoksil menghilang setelah hidrolisis, gugus guaiasil terdeteksi pada batok kelapa setelah proses hidrolisis, adanya cincin aromatik yang berkaitan dengan lignin pada masing-masing sampel sebelum dan setelah hidrolisis, serta gugus siringil pada sabut kelapa sebelum dan setelah proses hidrolisis.
\end{abstract}

Kata kunci: batok, sabut, kelapa, lignin, hidrolisis, asam sulfat

\section{Pendahuluan}

Biomassa lignoselulosa merupakan salah satu sumber daya alam yang dapat dimafaatkan karena mudah diperoleh, murah, ramah lingkungan, dan renewable. Biomassa lignoselulosa terdiri dari lignin dan selulosa yang dapat diperoleh dari limbah pertanian (Zabed dkk., (2017)). Biomassa lignoselulosa dapat dimanfaatkan sebagai bahan baku produksi komoditas bernilai tinggi berupa bahan bakar (bioetanol \& biodiesel), pelarut (aseton \& butanol), dan bahan kimia khusus (asam asetat $\&$ furfural) (Loow dkk., (2017)).

Lignoselulosa dapat diperoleh dengan proses hidrolisis untuk memecahkan polimer selulosa dan hemiselulosa menjadi monomer gula (glukosa atau xilosa) yang dapat dikonversi lagi menjadi berbagai macam senyawa (Ishola dkk., (2015)). Salah satu metode hidrolisis lignoselulosa yang umum digunakan adalah 
hidrolisis asam sulfat dalam temperatur tinggi (Zabed dkk., (2017)), karena desain dan kontrol proses yang tidak rumit serta alat dan bahannya murah serta relatif mudah didapat (Rajan dan Carrier, (2014)).

Metode Klason merupakan metode untuk menganalisa lignin secara kuantitatif. Lignin yang diisolasi dalam metode hidrolisis asam disebut lignin Klason. Metode ini ada dua tahap, yaitu pada konsentrasi tinggi sebesar $72 \%$ dengan temperatur rendah $10-15^{\circ} \mathrm{C}$ kemudian mengencerkan asam hingga $3 \%$ dan dipanaskan. Lignin yang diperoleh berupa residu (lignin tidak larut asam) dan filtrat (lignin larut asam). Kadar lignin larut asam pada filtrat lebih sedikit daripada kadar lignin tidak larut asam (Brauns dan Brauns, (2013)).

Limbah sabut kelapa dan batok kelapa merupakan contoh lain yang dapat dimanfaatkan untuk diperoleh ligninnya. Sabut kelapa mengandung lignin sebesar $33 \%$ dari berat kering total (Váquez-Torres dkk., 1992), sedangkan batok kelapa memiliki kadar lignin sebesar 48\% dari berat kering (Gupta dkk., (2016)).

\section{Bahan dan Metode}

Bahan yang digunakan yaitu limbah kelapa tua yang diperoleh di daerah Serpong Utara, Tangerang Selatan, $\mathrm{H}_{2} \mathrm{SO}_{4}$ (asam sulfat), dan akuades.

Peralatan yang digunakan yaitu hot plate, heating mantle, gelas beaker, labu refluks, termometer, kondenser, pompa, ember, ayakan (40 mesh dan 100 mesh), kertas saring, grinder, mortar dan alu, pinset, pipet, neraca analitik, oven, pengaduk, water bath, spektrofotometer UV-Vis (Libra S12), FT-IR (Thermo Scientific Nicolet iS10), dan SEM (Quanta 650).

Penelitian ini dimulai dari memisahkan bagian sabut dengan batok menggunakan pinset, kemudian dikeringan pada temperatur ruang. Sabut kelapa digiling, sedangkan pada batok kelapa ditumbuk dan dilanjutkan dengan proses penggilingan. Bahan diayak kemudian disimpan.

Proses hidrolisis lignin dengan asam sulfat $72 \%$ dilakukan berdasarkan standar TAPPI (Technical Association of the Pulp and Paper Industry). Sebanyak tiga gram sampel sabut atau batok kelapa kering dimasukkan ke dalam gelas beaker dan ditambahkan $\mathrm{H}_{2} \mathrm{SO}_{4} 72 \%$ sebanyak $25 \mathrm{ml}$. Gelas beaker direndam ke 
dalam water bath pada $20^{\circ} \mathrm{C}$ selama dua jam. Kemudian campuran tersebut dipindahkan ke labu bulat dan ditambahkan akuades sebanyak 560 ml. Refluks dilakukan dengan variasi waktu 2 hingga 5 jam. Residu disaring dari filtratnya dan dicuci dengan akuades panas, kemudian dikeringkan. Proses hidrolisis dilakukan dengan menggunakan dua alat refluks yang dirangkai seperti yang ditunjukkan pada Gambar 1 dan pengambilan data dilakukan secara duplo.

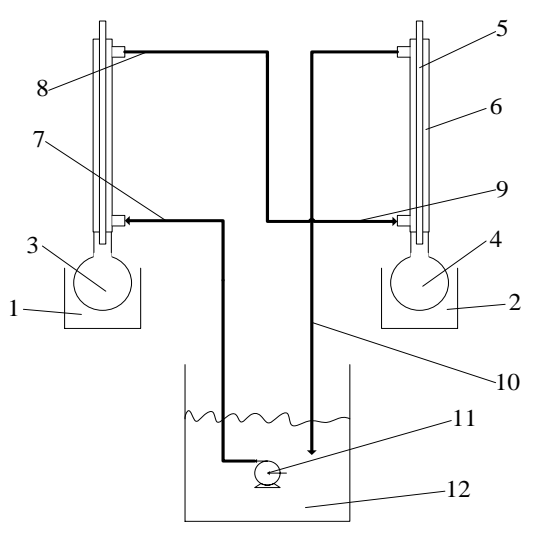

Gambar 1. Skema rangkaian alat refluks

dimana,

1. Heating mantle 1; 2. Heating mantle 2; 3 . Labu refluks 1; 4. Labu refluks 2; 5. Kondenser bagian dalam (aliran gas); 6. Kondenser bagian luar (aliran air pendingin); 7. Aliran air pendingin masuk (labu refluks 1); 8. Aliran air pendingin keluar (labu refluks 1); 9. Aliran air pendingin masuk (labu refluks 2); 10. Aliran air pendingin keluar (labu refluks 2); 11. Pompa; 12. Air pendingin

Pada analisis kadar abu, residu dipanaskan dengan furnace Nabertherm 30-3000 $\mathrm{C}$. Kadar abu dihitung menggunakan persamaan berikut.

$\operatorname{Abu}(\%)=\left(m_{\text {abu }} / m_{\text {biomassa kering }}\right) \times 100 \%$

dimana,

$\mathrm{m}_{\mathrm{abu}}=$ massa $\mathrm{abu}(\mathrm{gram}) ; \mathrm{m}_{\text {biomassa kering }}=$ berat kering sampel $(\mathrm{gram})$ 
Kadar lignin terlarut dan tidak terlarut dihitung berdasarkan standar LAP (Laboratory Analytical Procedure) (Sluiter dkk., (2012)) dengan menggunakan persamaan berikut.

Lignin terlarut $(\%)=(($ Absorbansi $x 1 \times(585 / 1000)) /(9.1642 x$

$$
m_{\text {biomassa kering })) \times 100 \%}
$$

Lignin tidak terlarut $(\%)=\left(m_{\text {residu }}-m_{\text {abu }}\right) /\left(m_{\text {biomassa kering }}\right) \times 100 \%$

dimana,

$m_{\text {residu }}=$ massa residu $($ gram $) ; m_{a b u}=$ massa abu $($ gram $) ; 1=$ faktor pengenceran; 9.1642 = faktor konversi dari absorbansi $330 \mathrm{~nm}(1 / \mathrm{g} . \mathrm{cm})(\mathrm{Guo},(2013)) ; 585=$ volume total cairan; $1000=$ faktor konversi $\mathrm{ml} \mathrm{ke} 1$;

\section{Hasil dan Diskusi}

\subsection{Sifat Fisik dan Kadar Air Bahan Baku}

Berdasarkan Gambar 2, batok kelapa memiliki kadar air lebih sedikit (6.35\%) jika dibandingkan dengan sabut kelapa (7.67\%). Hal ini disebabkan adanya mikropori alami pada serbuk dan serat kelapa, sehingga sabut kelapa bersifat sangat hidrofilik (Raviv dkk., (2019)).

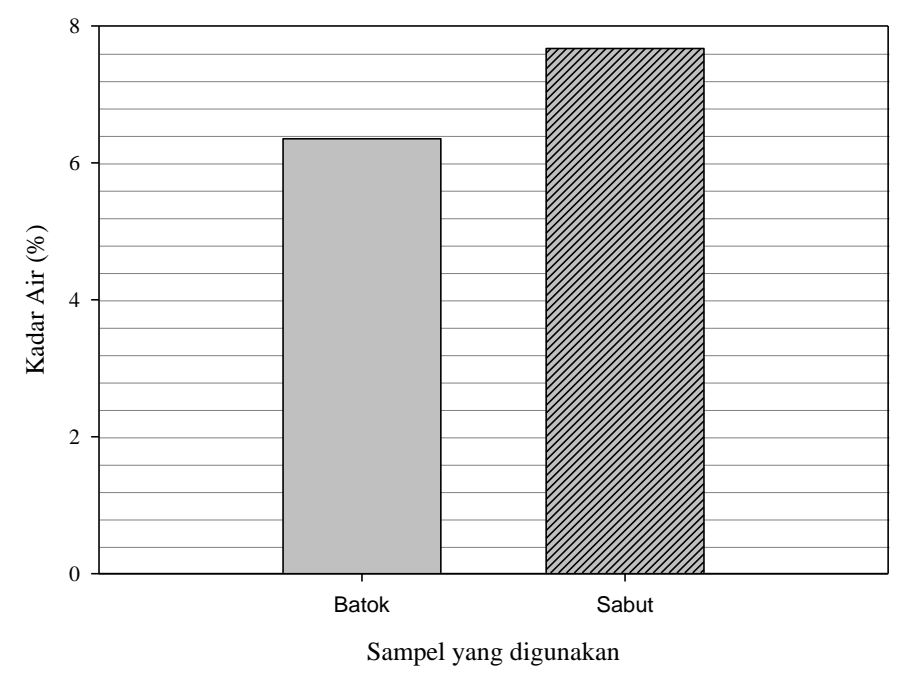

Gambar 2. Hasil analisa kadar air pada sampel sebelum hidrolisis asam sulfat 


\subsection{Analisis Komponen Padatan atau Residu Hasil Hidrolisis Asam Sulfat}

Pada Gambar 3, persentase yield lignin residu pada batok kelapa refluks 1 meningkat hingga waktu 4 jam lalu menurun pada waktu 5 jam. Namun pada alat refluks 2, yield yang diperoleh mengalami peningkatan pada waktu 3 jam dan menurun secara drastis. Sabut kelapa pada refluks 1 dan 2 terlihat kecenderungannya hampir serupa. Berdasarkan hasil yang diperoleh, diketahui yield lignin tidak larut asam yang diperoleh dari batok kelapa lebih banyak jika dibandingkan dengan sabut kelapa.

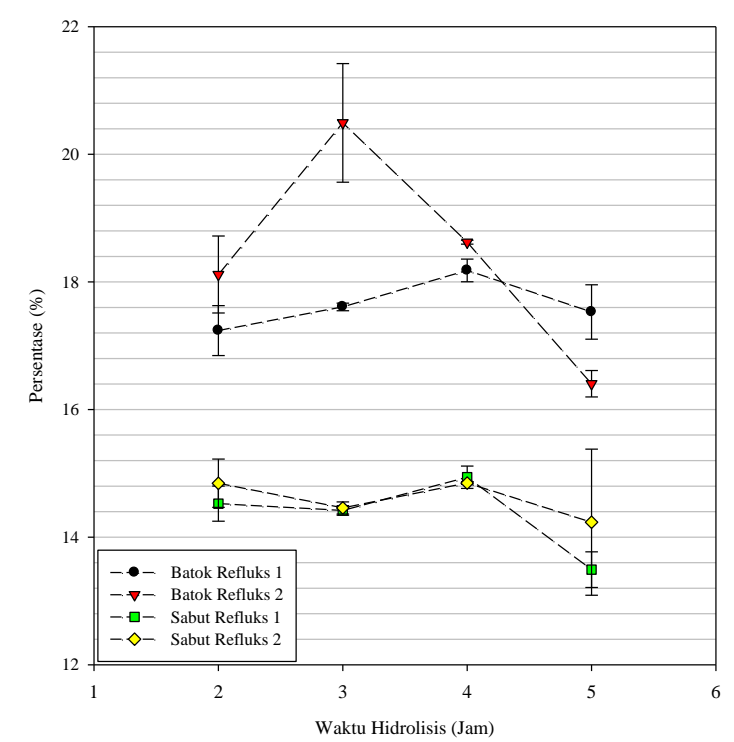

Gambar 3. Hasil yield lignin tidak larut dalam asam rata-rata dari residu hasil

hidrolisis asam sulfat batok dan sabut kelapa

Peningkatan yield disebabkan oleh hidrolisis polisakarida yang tidak larut dalam suspensi asam ketika dipanaskan dengan asam sulfat 3\% karena struktur mikrofibril selulosa membengkak dan rusak (Yasuda dkk., (2001)). Namun, zat pengotor dapat memengaruhi perhitungan yield karena bisa dianggap sebagai lignin. Zat pengotor ini berasal dari proses preparasi sampel (Akpan dan Adeosun, (2019)), dan adanya kontaminan residu karbohidrat (hemiselulosa dan selulosa), protein, dan garam anorganik lain (Beckham, (2018)). 


\subsection{Analisis Komponen Filtrat Hasil Hidrolisis Asam Sulfat}

Yield lignin larut asam yang diperoleh pada batok kelapa lebih banyak daripada sabut kelapa, karena batok kelapa mengandung lignin lebih banyak daripada sabut kelapa (Váquez-Torres dkk., (1992); Gupta dkk., (2016)). Hasil analisa yield lignin larut dalam asam dari residu hasil hidrolisis asam sulfat batok dan sabut kelapa ditunjukkan pada Gambar 4.

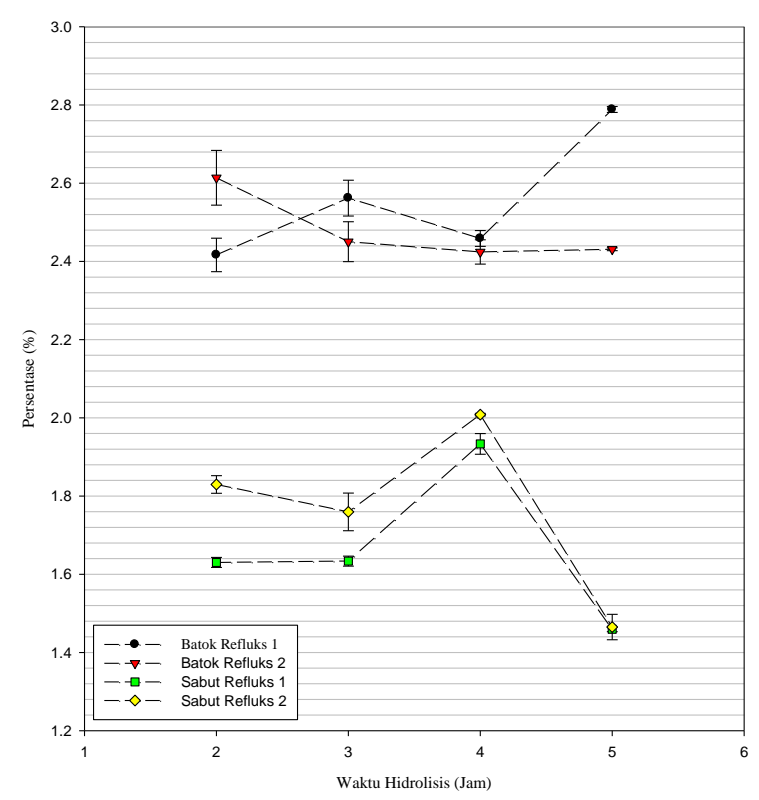

Gambar 4. Hasil yield lignin larut dalam asam rata-rata dari filtrat hasil hidrolisis asam sulfat batok dan sabut kelapa

Kemungkinan perbedaan yield lignin larut asam pada batok kelapa dapat disebabkan oleh pengaturan heating mantle, karakteristik lignoselulosa, proses difusi, dan pra perendaman lignoselulosa dengan asam (Gupta dan Tuohy, (2013)). Penentuan yield lignin larut asam dengan UV-Vis spektroskopi juga dipengaruhi realiabilitas nilai absorptivitas, pembentukan produk degradasi karbohidrat yang menyerap pada lambda tertentu, hidrolisis parsial gugus ester dalam lignin, dan hilangnya beberapa gugus metoksil sebagai metanol sebagai akibat dari hidrolisis dengan asam sulfat (Calvo-Flores dkk., (2015); Lin dan Dence, (2012)). Adanya zat pengotor yang aktif terhadap sinar UV pada panjang 
gelombang khas lignin juga dapat mengubah pengukuran lignin yang larut dalam asam (Beckham, (2018)).

\subsection{Analisis FT-IR Komponen Padatan/Residu Hasil Hidrolisis Asam Sulfat}

Sampel lignin tidak larut asam yang digunakan berasal dari sampel batok perlakuan 3 jam refluks dan sampel sabut dari perlakuan 4 jam refluks. Pemilihan sampel berdasarkan hasil yield lignin tidak larut asam tertinggi dari masingmasing bahan.

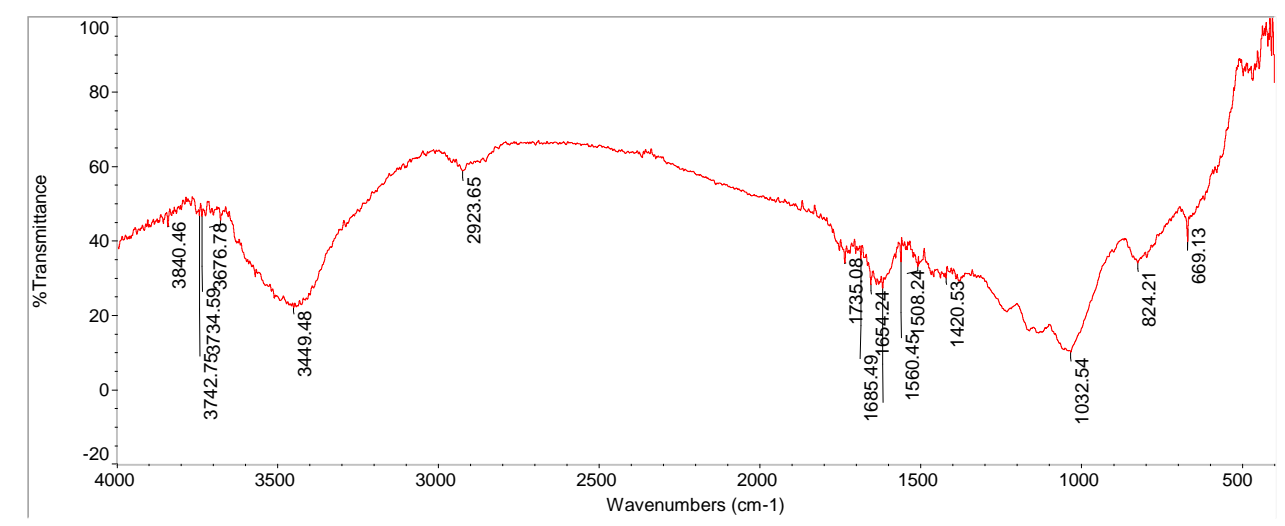

Gambar 5. Hasil pengukuran spektrum FT-IR batok kelapa sebelum hidrolisis asam sulfat

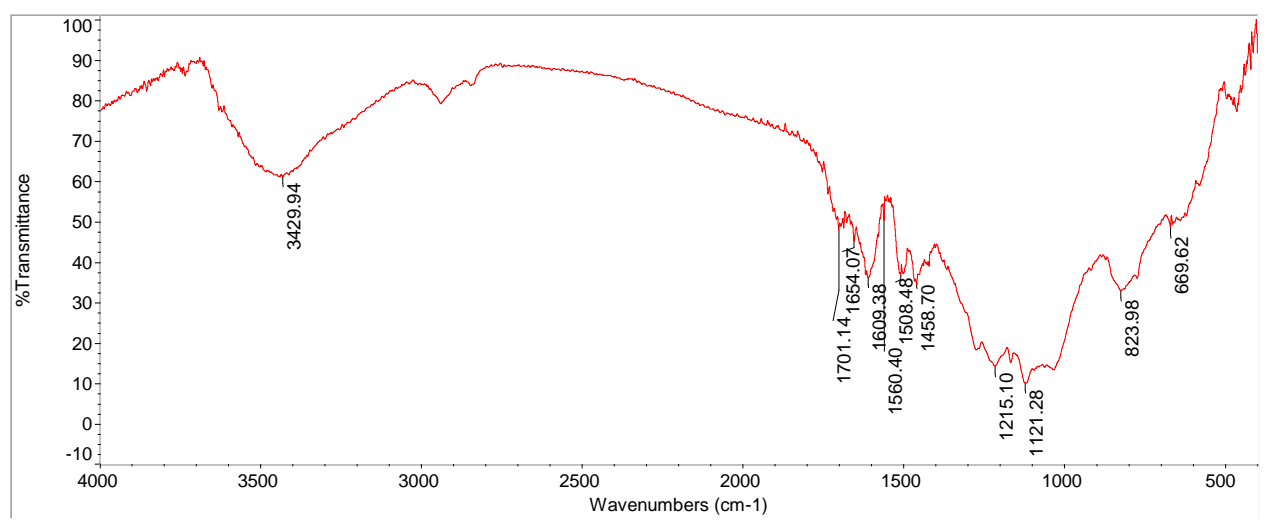

Gambar 6. Hasil pengukuran spektrum FT-IR batok kelapa (perlakuan refluks 3 jam) setelah hidrolisis asam sulfat 
Pada rentang 3700-3100 $\mathrm{cm}^{-1}$ batok kelapa terdeteksi lima peak, namun setelah hidrolisis hanya ada satu peak, sedangkan pada sabut kelapa sebelum dan setelah hidrolisis ada satu buah peak terdeteksi dengan intensitas yang berbeda. Rentang ini merupakan karakteristik gugus hidroksi dan regangan vibrasi ikatan $\mathrm{OH}$. Hal ini disebabkan kadar selulosa, hemiselulosa, dan lignin dipengaruhi proses chemical treatment (Ghaffar dan Fan, (2013); Kalia, (2017)).

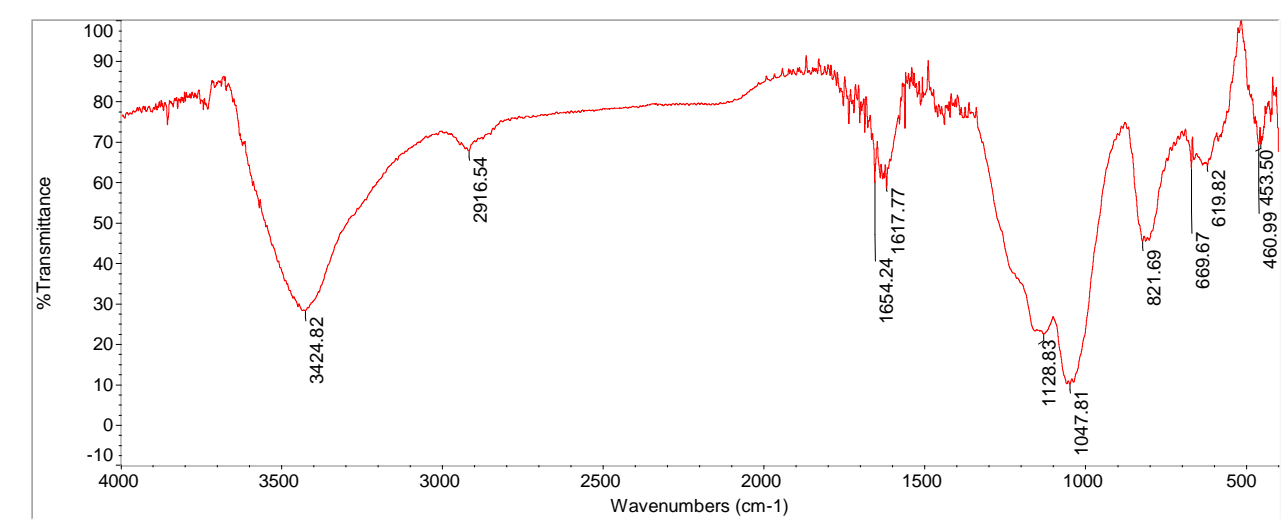

Gambar 7. Hasil pengukuran spektrum FT-IR sabut kelapa sebelum hidrolisis asam sulfat

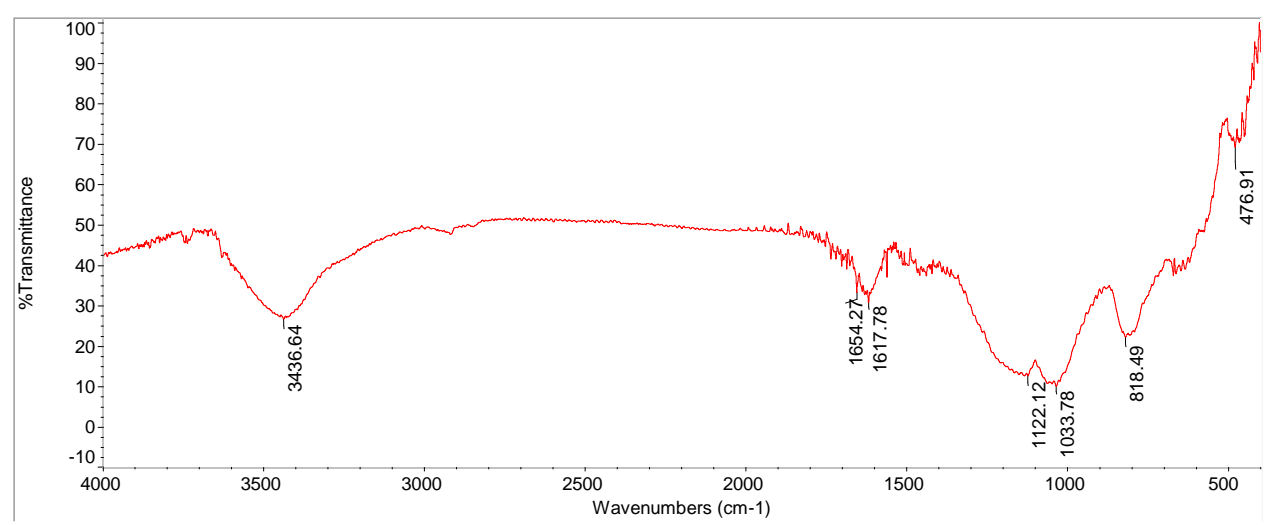

Gambar 8. Hasil pengukuran spektrum FT-IR sabut kelapa (perlakuan refluks 4 jam) setelah hidrolisis asam sulfat

Pada batok sebelum dan setelah hidrolisis, muncul peregangan $\mathrm{C}=\mathrm{C}$ dan $\mathrm{C}=\mathrm{O}$ pada cincin aromatik lignin. Selain itu, pada batok sebelum hidrolisis juga dideteksi rentang vibrasi cincin aromatik pada lignin dan setelah hidrolisis ada 
dua peak gelombang $\left(1215.10 \mathrm{~cm}^{-1}\right.$ dan $\left.1121.28 \mathrm{~cm}^{-1}\right)$ yang menunjukkan gugus C-O cincin guaiasil. Pada sabut kelapa sebelum dan setelah hidrolisis, gugus siringil terdeteksi masing-masing sebesar $1128.83 \mathrm{~cm}^{-1}$ dan $1122.12 \mathrm{~cm}^{-1}$. Gugus guaiasil dan siringil menunjukkan adanya lignin (Hon dan Shiraishi, (2000)). Banyaknya peak yang membuktikan bahwa lignin batok kelapa lebih banyak daripada sabut kelapa (Váquez-Torres dkk., (1992); Gupta dkk., (2016)).

\subsection{Analisis SEM Residu Hasil Proses Hidrolisis Asam Sulfat}

Sampel yang digunakan dalam uji SEM ini adalah sampel batok kelapa sebelum dan setelah proses refluks selama 3 jam serta sampel sabut kelapa sebelum dan setelah proses refluks selama 4 jam dengan masing-masing perbesaran $100 \mathrm{x}$.

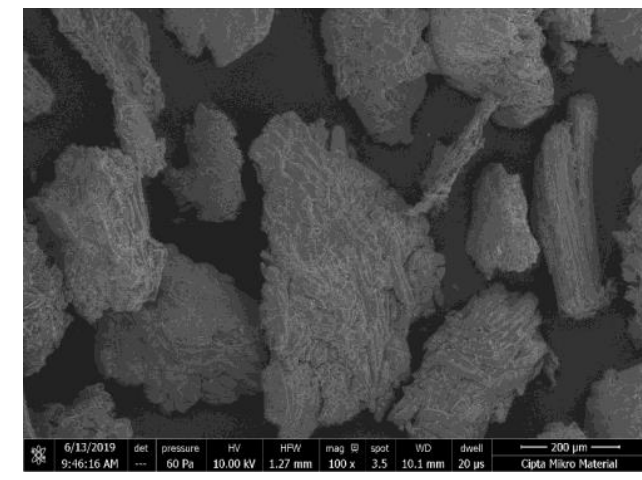

Gambar 9. Hasil SEM batok kelapa sebelum hidrolisis

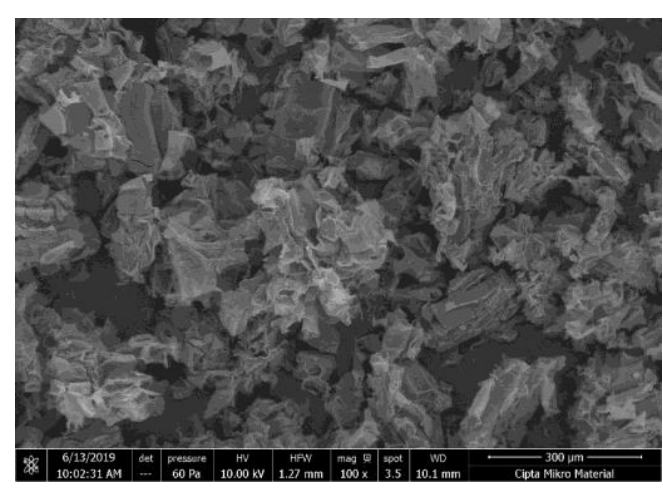

Gambar 11. Hasil SEM sabut kelapa sebelum hidrolisis

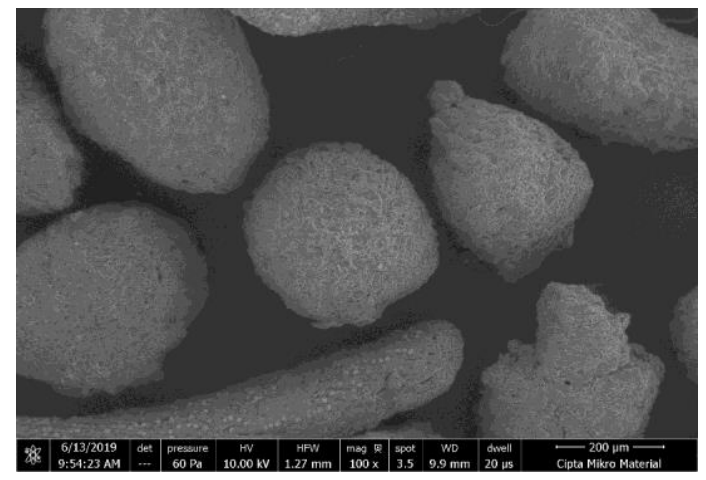

Gambar 10. Hasil SEM batok kelapa sesudah hidrolisis

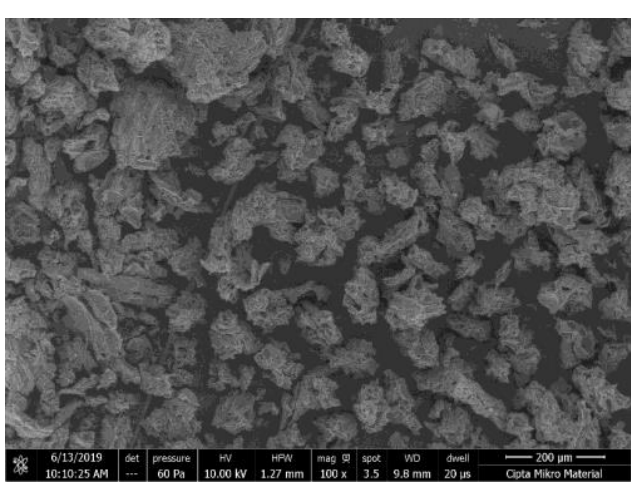

Gambar 12. Hasil SEM sabut kelapa sesudah hidrolisis 
Pada Gambar 9 sampel batok kelapa sebelum hidrolisis tampak lebih besar (salah satu partikel berukuran sekitar $374 \mu \mathrm{m}$ ) dan permukaannya tidak beraturan serta kasar, di mana pada Gambar 10 terlihat ukuran partikel lebih kecil (salah satu partikel berukuran sekitar $354 \mu \mathrm{m}$ ). Begitu pula dengan partikel sabut kelapa (Gambar 11) sebelum hidrolisis tampak saling bertumpang tindih satu dengan yang lain karena ukurannya lebih besar (salah satu partikel berukuran sekitar 285 $\mu \mathrm{m}$ ), namun setelah hidrolisis (Gambar 12) partikelnya jauh lebih kecil (salah satu partikel berukuran sekitar $71 \mu \mathrm{m})$.

Berkurangnya ukuran partikel disebabkan karena larutnya hemiselulosa dalam asam sulfat dan adanya perubahan struktur lignin. Asam sulfat digunakan untuk menghidrolisa dan mendepolimerisasi polisakarida batok dan sabut kelapa. Chemical treatment akan mengakibatkan ikatan antara lignin, hemiselulosa, dan selulosa dari suatu material lignoselulosa akan rusak (Galiwango dkk., (2018); Thakur, (2014)).

\section{Simpulan dan Saran}

Rata-rata yield lignin tidak larut asam terbesar pada batok kelapa sebesar $20.49 \%$ dan sabut kelapa sebesar 14.94\%, sedangkan yield lignin larut asam terbesar pada batok kelapa sebesar $2.79 \%$ dan sabut kelapa sebesar 2.01\%. Waktu optimum hidrolisis batok dan sabut kelapa berturut-turut pada waktu refluks 3 jam dan 4 jam, sedangkan untuk memeroleh lignin larut asam pada batok dan sabut kelapa berturut-turut berada pada waktu refluks 5 jam dan 4 jam. Gugus metoksil menghilang setelah hidrolisis, adanya cincin aromatik yang berkaitan dengan lignin sebelum dan setelah hidrolisis, dan gugus guaiasil terdeteksi pada batok kelapa setelah hidrolisis serta gugus siringil terdeteksi pada sabut kelapa sebelum dan setelah hidrolisis. Pada uji karakterisasi morfologi, adanya pengurangan ukuran disebabkan karena larutnya hemiselulosa dalam asam sulfat dan adanya perubahan struktur lignin.

Penelitian selanjutnya dapat menggunakan metode pemerolehan lignin yang lain dengan menggunakan bahan limbah lignoselulosa yang lain. 


\section{Daftar Pustaka}

1. Akpan, E., dan Adeosun, S. (2019), Sustainable Lignin for Carbon Fibers: Principles, Techniques, and Applications, Springer.

2. Beckham, G.T. (Ed.) (2018), Lignin Valorization: Emerging Approaches (Vol. 19), Royal Society of Chemistry.

3. Brauns, F., dan Brauns, D. (2013), The Chemistry of Lignin: Covering the Literature for the Years 1949 - 1958, Elsevier.

4. Calvo-Flores, F., dkk (2015), Lignin and lignans as renewable raw materials: chemistry, technology and applications, John Wiley \& Sons.

5. Galiwango, E., dkk (2018), "Klason Method: An Effective Method for Isolation of Lignin Fractions from Date Palm Biomass Waste", Chemical and Process Engineering Research, Res, 57, 46 - 58.

6. Ghaffar, S., dan Fan, M. (2013), Structural analysis for lignin characteristics in biomass straw, Biomass and Bioenergy, 57, $264-279$.

7. Guo, M. (2013), Life cycle assessment (LCA) of light-weight eco-composites, Springer Science \& Business Media.

8. Gupta, V., dan Tuohy, M. (2013), Biofuel Technologies: Recent Developments, Editorial Springer.

9. Gupta, V., dkk (2016), The Handbook of Microbial Bioresources, CABI.

10. Hon, D.-S., dan Shiraishi, N. (2000), Wood and Cellulosic Chemistry, Second Edition, Revised, and Expanded, CRC press.

11. Ishola, M. M., dkk (2015), "Simultaneous glucose and xylose utilization for improved ethanol production from lignocellulosic biomass through SSFF with encapsulated yeast", Biomass and Bioenergy, 77(1), 192 - 199.

12. Kalia, S. (Ed.) (2017), Lignocellulosic Composite Materials, Springer.

13. Lin, S., dan Dence, C. (2012), Methods in Lignin Chemistry, Springer Science \& Business Media.

14. Loow, Y. -L., dkk (2017). "Potential use of deep eutectic solvents to facilitate lignocellulosic biomass utilization and conversion”, Cellulose, 24(9), 3591 3618 . 
15. Rajan, K., dan Carrier, D. J. (2014), "Effect of dilute acid pretreatment conditions and washing on the production of inhibitors and on recovery of sugars during wheat straw enzymatic hydrolysis", Biomass and Bioenergy, 62(1), $222-227$.

16. Raviv, M., dkk (Ed.) (2019), Soilless Culture: Theory and Practice: Theory and Practice, Elsevier.

17. Sluiter, A., dkk (2012), Determination of Structural Carbohydrates and Lignin in Biomass, National Renewable Energy Laboratory (NREL), Colorado.

18. TAPPI, T. (2002), 222 om-02: Acid-insoluble lignin in wood and pulp, 20022003 TAPPI Test Methods.

19. Thakur, V. K. (2014), Lignocellulosic Polymer Composites: Processing, Characterization, and Properties, John Wiley \& Sons.

20. Váquez-Torres, H., dkk (1992). "Coconut husk lignin. I. Extraction and characterization". Journal of applied polymer science, 45(4), 633 - 644.

21. Yasuda, S., dkk (2001), "Formation and chemical structures of acid-soluble lignin I: sulfuric acid treatment time and acid-soluble lignin content of hardwood", Journal of Wood Science, 47(1), 69 - 72.

22. Zabed, H., dkk (2017), "Bioethanol production from renewable sources: Current perspectives and technological progress", Renewable and Sustainable Energy Reviews, 71(1), 475 - 501. 